\title{
Porous Materials in the Bioprocessing Area
}

\section{Mirna L Sanchez ${ }^{1,2^{\star}}$, Marcelo Fernandez Lahore ${ }^{2}$ and Mariano Grasselli}

${ }^{1}$ Laboratorio de Materiales Biotecnológicos (LaMaBio), Universidad Nacional de Quilmes-IMBICE (CONICET-CICPBA), Bernal, Argentina

${ }^{2}$ Downstream Processing Lab, Jacobs University Bremen, Bremen, Germany

The modern life science industry is facing a real challenge to deliver new products to a highly demanding and regulated market. As a consequence, bioprocess technology options have become limited considering total available manufacturing capacity and process efficiency and cost. The bioprocess technology can be divided into two main parts, namely upstream (fermentation) and downstream (separation and purification).

A critical analysis of the current bioprocess technology reveals that the fermentative processes are in a mature phase and numerous technological developments in heterologous protein expression are already being used.

Rapid developments in biotechnology and the pharmaceutical potential of biomolecules are fueling demand for reliable, efficient methods to purify preparative amounts of proteins, peptides and nucleic acids. The recovery and purification of bio products is based on chromatographic separations. However, it still has a significant number of challenges to be solved.

Current limitations in bead-packed column-liquid chromatography include a relatively time-consuming and high-pressure packing process, a high-pressure drop in the columns and the slow diffusion of solutes within the pores of the bead matrix.

The low productivity imposed by diffusional limitations, the need for multiple chromatographic steps, and the requirement of extensive solid separation drives to a technological situation characterized by low global product yields. In addition the slow intra-particle diffusion of high-molecular-weight solutes such as proteins within the porous beads of the industrial columns reduces the dynamic binding capacity.

As a consequence, the separation and purification schemes applied in the biopharmaceutical industry for the purification of biotherapeutics require novel solutions to improve the downstream processing. One strategy for process improvements is the development of alternative materials to replace the traditional packed-bed columns.

In the last years, in order to intensificate and integrate the downstream processing tasks new porous materials were designed, for example microfiltration membranes [1], monolithics [2] cryogeles [3] reticulated polyurethane foams (rPUF) [4].

The strategy with these materials is to process directly non-clarified homogenate improving product separation by adsorbents with high affinity and adsorption capacity, reversible interactions and sufficient robustness for process scale applications.

Several approximations have been proposed for the previous mentioned intensification/integration. In the last years a capture system based on porous monolithic materials $(10-100 \mu \mathrm{m}$ of mean pore diameter) called cryogels has been described. These porous materials have the capability of processing raw samples without prechromatographic treatment. This property have great implications in reducing cost and time of a bioprocess, as well as in simplifying the steps of isolating a protein.

There are other materials with a high capacity to absorb water (several times its weight) commonly called hydrogels. This property allows them to be used in various technological areas [5], for example as a material for the purification of proteins. However these materials need to be chemically cross-linked to improve the mechanical properties. A compromise between the mechanical and adsorptive properties is the main weakness. In this type of materials the adsorption process is diffusion-limited.

One interesting option to avoid this limitation is to develop a continuous porous solid material, called monoliths. In the last decade porous monolithic polymeric materials have been extensively studied due to their potential applications in the separation of macromolecules [6]. The interconnected macroporous channels can facilitate mass transport $[7,8]$. Therefore, monolithic columns with these unique structures enable high flow rates at low back pressure without drop in column efficiency, resulting in fast separation. Monolithic porous materials have the advantage to operate at high flow rates. However, these materials have a limited internal surface that provides a low availability of functional ligands [9].

A matrix to be selected as a competitive material for protein purification should have high adsorptive capacity. One way to increase the capacity is to create chains of hydrophilic polymers on the surface of a material on which the ligands will be immobilized. To achieve this goal there are different procedures. In situ radiation-induced graft polymerization is a promising straightforward technique in this area [10].

Modification of porous materials surface or in the bulk through the direct activation using ionizing radiations, such as electron accelerators [11], or gamma rays source [10] have been applied to the development of adsorptive materials. Surface modification can confer reactivity and new physicochemical properties. Currently, some materials are modified in order to use them as new systems for ion exchange chromatographic separation [12,13], adsorptive fibers with high capacity immobilizing pseudo-affinity ligands $[14,15]$ or as a support for immobilization of enzymes and cells [16]. The application of these materials to a real purification process has been demonstrated $[13,17]$.

Monoliths and cryogels have very good hydrodynamic properties however they have very low adsorption capacities. One attempt to improve this property was recently reported by a co-worker research group. Cryogels with improved capacity were obtained by the previous mentioned technique, radiation-induced graft polymerization [18].

*Corresponding author: Mirna L Sanchez, Laboratorio de Materiales Biotecnológicos (LaMaBio), Universidad Nacional de Quilmes-IMBICE (CONICETCICPBA), Bernal, Argentina, Tel: 54-11-4365-710; E-mail: mirna.sanchez@unq.edu.ar

Received April 27, 2015; Accepted August 07, 2015; Published August 12, 2015

Citation: Sanchez ML, Lahore MF, Grasselli M (2015) Porous Materials in the Bioprocessing Area. J Bioprocess Biotech 5: 247 doi:10.4172/2155-9821.1000247

Copyright: () 2015 Sanchez ML, et al. This is an open-access article distributed under the terms of the Creative Commons Attribution License, which permits unrestricted use, distribution, and reproduction in any medium, provided the original author and source are credited. 


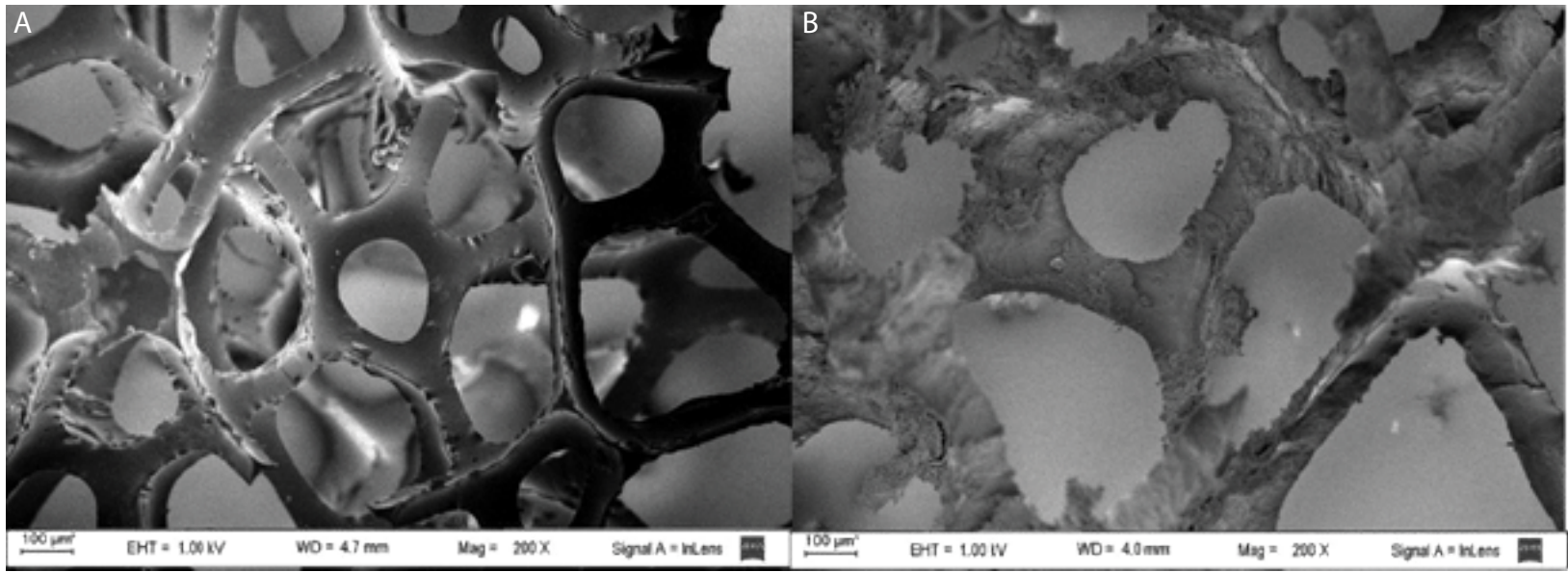

Figure 1: SEM images of $(A)$ the base material rPUF $(B)$ modified rPUF.

Nevertheless, cryogels have an important challenge to be solved: preparation in large scale, therefore these materials will be limited to laboratory scale applications.

In order to overcome the preparation of the porous structure, in our last research was chosen an industrial source of open-porous material. Reticulate polyurethane foams meets with this requirement. It is a chemically inert material with tridimensional structure, excellent mechanical properties (high resistance and elasticity), bulk availability and low commercial cost. rPUF has a high porosity (near 97\%) and highly structured opened macrostructure. As an elastic material, the flexibility of rPUF also provides good stability and resistance to compression deformation.

In order to obtain a material with protein adsorption capacity, it is proposed to produce a modified reactive foam to be used as chromatographic matrix.

Radiation-induced graft polymerization technique is a powerful methodology for surface modification. The adequate sample preparation and irradiation conditions are the critical issue to success in the preparation of a novel material. In a similar way, swelled cellulose fibers [19] and cryogels [18] has been successfully modified by this technique.

Despite its adsorptive properties, packed-bed chromatography normally requires extensive sample preparation, including a high degree of clarification in order to avoid column blockage and adsorbent fouling. In the last decade, polymeric (macro to mega) porous materials have been introduced for biomolecules capture, which, in some cases, avoid the extensive removal of biomass from fermentation broths.

Our research group proposed reticulated polyurethane foam (rPUF) as base material to be modified in order to obtain a new chromatographic matrix because it provides mechanical resistance and it's intrinsically shape (open pore). In Figure 1 it is shown electron microscopy images of the base rPUF material and the modified one.

Using rPUF material was avoided disadvantages such as diffusion and clogging of classic materials (beads) and resistance of porous materials (monoliths and cryogels). Hydrodynamic characterization is currently studied in detail in order to obtain the maximum process productivity of this novel material.
Other application of the porous materials is like storages materials. Its characteristic structure is the responsible of excellent mechanical properties, low thermal conductivity, good damping capacity, low permeability, low density and the most important one energy absorption capacity. Nowadays the trend on the development of porous-energy-absorbing materials mainly is focused on polyurethane foam $[20,21]$ and foamed aluminum $[22,23]$. These new storages devices are crucial in the energy area because they have useful for conserving energy, reducing the environmental impact. Porous materials can be impregnated with phase change material for thermal energy storage in order to efficiently recover waste heat in the form of latent heat [12]. Other example of porous material used as storages is the activated porous carbons employed in gas adsorption or gas storage [24] and as a catalyst support [25]. Cellular ceramics, other type of porous material, are used in several applications in many industrial fields like catalyst supports, hot gas filter, particle filter and gas membrane [26].

The versatile applications mentioned before produced an expansion of the materials science field especially in the development of new porous materials to be applied in bioprocess area

\section{Acknowledgments}

The authors thanks the support of CONICET, Argentinean grants from Ministry of Science, Technology and Productive Innovation (MINCYT), Universidad Nacional de Quilmes (UNQ) and European Union Seventh Framework Programme (FP7/2007-2013) under Grant Agreement No. 312004

\section{References}

1. Baker RW (2004) Membrane Technology and Applications. John Wiley \& Sons, USA.

2. Svec F, Tennikova TB, Deyl Z (2003) Monolithic Materials: Preparation, Properties and Applications. Elsevier, The Netherlands.

3. Mattiasson B, Ashok Kumar, Galeaev IY (2009) Macroporous Polymers: Production Properties and Biotechnological/Biomedical Applications. CRC Press.

4. Cui C, Tao Y, Li L, Chen B, Tan T (2013) Improving the Activity and Stability of Yarrowia Lipolytica Lipase Lip2 by Immobilization on PolyethyleneimineCoated Polyurethane Foam. J Mol Catal B Enzym 91: 59-66.

5. Hoffman AS (2002) Hydrogels for biomedical applications. Adv Drug Deliv Rev 54: 3-12.

6. Park JS, Kuang J, Gwon HJ, Lim YM, Jeong SI, et al. (2013) Synthesis and characterization of zinc chloride containing poly(acrylic acid) hydrogel by gamma irradiation. Radiat Phys Chem 88: 60-64 
Citation: Sanchez ML, Lahore MF, Grasselli M (2015) Porous Materials in the Bioprocessing Area. J Bioprocess Biotech 5: 247 doi:10.4172/21559821.1000247

7. Zhang M, Sun Y (2001) Poly(glycidyl methacrylate-divinylbenzenetriallylisocyanurate) continuous-bed protein chromatography. J Chromatogr A 912: 31-38.

8. Cabrera K, Lubda D, Eggenweiler HM, Minakuchi H, Nakanishi K (2000) A New Monolithic-Type HPLC Column For Fast Separations. J High Resolut Chromatogr 23: 93-99.

9. Plieva FM, Andersson J, Galaev IY, Mattiasson B (2004) Characterization of polyacrylamide based monolithic columns. J Sep Sci 27: 828-836.

10. Grassellia M, del Cañizoa AAN, Camperia SA, Wolmana FJ, Smolkob EE, et al (1999) Immobilized metal ion affinity hollow-fibre membranes obtained by the direct grafting technique. Radiat Phys Chem 55: 203-208.

11. Grasselli M, Carbajal ML, Yoshii F, Sugo T (2003) Radiation-induced GMA DMAA graft copolymerization onto porous PE hollow-fiber membrane. J App Polym Sci 87: 1646-1653

12. Nomura T, Okinaka N, Akiyama T (2009) Impregnation of porous material with phase change material for thermal energy storage. Mater Chem Phys 115: 846

13. Ventura AM, Fernandez Lahore HM, Smolko EE, Grasselli M (2008) High-speed protein purification by adsorptive cation-exchange hollow-fiber cartridges. J Membr Sci 321: 350-355

14. Wolman FJ, Smolko EE, Cascone O, Grasselli M (2005) Improved hollow-fibre membranes for dye-affinity chromatography. J Sep Sci 28 : 45-51.

15. Carbajal ML, Espinoza SLS, Valdez SN, Poskus E, Smolko EE, et al. (2009) Arsenical grafted membranes for immobilization of thioredoxin-like proteins. React Funct Polym 69: 816-820.

16. Trelles JA, Quiroga F, Britos C, Smolko EE, Grasselli M (2010) Immobilization of bacteria in microgel grafted onto macroporous polyethylene. Radiat Phys Chem 79: 241-245
17. Wolman FJ, Grasselli M, Cascone O (2006) Rapid neutral protease purification by dye-affinity membrane chromatography. Process Biochem 41: 356-361.

18. Bibi NS, Singh NK, Dsouza RN, Aasim M, Fernández-Lahore M (2013) Synthesis and performance of megaporous immobilized metal-ion affinity cryogels for recombinant protein capture and purification. J Chromatogr A 1272: $145-149$

19. Fernandez-Lahore M, Grasselli M (2010) Composite material. US 20100065499 A1.

20. Gutiérrez-González S, Gadea J, Rodríguez A, Junco C, Calderón V (2012) Lightweight plaster materials with enhanced thermal properties made with polyurethane foam wastes. Construction and Building Materials 28: 653-658.

21. Zaretsky E, Asaf Z, Ran E, Aizik F (2012) Impact response of high density flexible polyurethane foam. Int J Impact Eng 39: 1-7.

22. Sun Z, Hu X, Sun S, Chen H (2013) Energy-absorption enhancement in carbonfiber aluminum-foam sandwich structures from short aramid-fiber interfacia reinforcement. Compos Sci Technol 77: 14-21.

23. Cho JU, Hong SJ, Lee SK, Cho C (2012) Impact fracture behavior at the material of aluminum foam. Mater Sci Eng: A 539: 250-258.

24. Zhang Q, Du Q, Jiao T, Zhang Z, Wang S, et al. (2013) Rationally designed porous polystyrene encapsulated zirconium phosphate nanocomposite for highly efficient fluoride uptake in waters. Sci Rep 3: 2551.

25. Xu B, Hou S, Cao G, Wu F, Yang Y (2012) Sustainable nitrogen-doped porous carbon with high surface areas prepared from gelatin for supercapacitors. Mater Chem 22: 19088-19093.

26. Green DJ (2003) Cellular ceramics: Intriguing structures, novel properties, and innovative applications. MRS Bulletin 28: 296-300.
Citation: Sanchez ML, Lahore MF, Grasselli M (2015) Porous Materials in the Bioprocessing Area. J Bioprocess Biotech 5: 247 doi:10.4172/2155 9821.1000247
Submit your next manuscript and get advantages of OMICS Group submissions

Unique features:

User friendly/feasible website-trans/a

Digital articles to

Special features:

400 Open Access Journals

30,000 editorial team

21 days rapid review process

Quality and quick editorial, review and publication processing

Indexing at PubMed (partial), Scopus, EBSCO, Index Copernicus and Google Scholar etc

Sharing Option: Social Networking Enabled

Authors, Reviewers and Editors rewarded with online Scientific Credits

Better discount for your subsequent articles

Submit your manuscript at: www.omicsonline.org/submission 